\title{
兵庫県南部地震における SRC 造建物の柱脚部の被害分析 \\ DAMAGE OF THE COLUMN BASES OF STEEL ENCASED REINFORCED CONCRETE BUILDINGS DUE TO 1995 HYOGO-KEN NANBU EARTHQUAKE
}

\author{
称 原良一*, 南 宏一** \\ Ryoichi SHOHARA and Koichi MINAMI
}

\begin{abstract}
We've examined steel encased reinforced concrete buildings whose column bases were severely damaged due to 1995 Hyogo-ken Nanbu earthquake. We've deduced the tension force due to overturning moment has caused these damages through statistical analysis of the data. We've also proposed the models to estımate the shear coefficient $\mathrm{C}_{\mathrm{B}}$ equivalent to the overturning strength of the building Those buildings whıch suffered severe damage at therr column bases had $C_{B}$ values less than 0.5 and/or had $C_{B}$ value lower the shear coefficient $C_{0}$ values which are estimated summing the shear strength of the columns and walls. Those buildings whose tensile strength of the column base overwhelms that of the column itself could also avoid the damage of the column base.
\end{abstract}

key words: Earthquake damage, SRC column base, Overturning moment,Tensile force, Anchor bolt, Base plate, 地震被害, S R C 柱脚，転倒曲げモーメント，引張力，アンカーボルト，ベースプレート

\section{1 はじめに}

兵庫県南部地震ではそれまでの地震ではほとんど報告されていな い, 中間層の崩壊などの破壊モードがいくつか起きた。S R C 造建物 の柱脚部の被害もその一つである。ここで柱脚部とは柱の下部をさす のではなく，SR C構造から R C 構造へ切り替わる鉄骨のベースプレ 一ト下部をさす。この被害は柱そのものが強い充腹形 S R C 構造の非 埋込柱脚に目立ったが，格子形 S R C 構造の場合や埋込み型の柱脚の 場合の被害もあった。充腹形 S R C造建物で柱や梁本体には被害があ まり見られないものの，柱脚部に大きな被害を受けた建物も多かった。 本論では日本建築学会・鋼コンクリート合成構造運営委員会及び $\mathrm{S} R$ C 耐震設計小委員会に寄せられた資料》や筆者等が直接得た资料等を 基に被害の状況を紹介し，被害原因について分析し，柱脚部の被害を 防ぐための条件を検討する。なお，本論は文献2)に既に発表している 部分を含めてまとめたものであり，その成果の一部はS R C 耐震診断 基準汭に採り入れられている。

\section{2 柱脚部被害の概要と検討対象建物}

S R C 造建物の柱脚は非埋込み柱脚と埋込み柱脚に大別される。非 埋込み柱脚は基䃈上にベースプレートを設置し, アンカーボルトで基 砒のコンクリートと結合し，その周りを鉄能で補強したものである。 兵庫県南部地㢳ではアンカーボルトや周りの鉄筋が破断したり, ベー
スプレート直下のコンクリートが圧壊している例が多い。多くの場合 は 1 階基整梁上に鉄骨が設置されているが, 地下部の基整梁上に設置 されている場合の被害もある。

埋込み柱脚の場合には被害件数は少ないが, フーチングが鉄骨ベー スプレート位置で破損している例がいくつかある。多くの埋込み柱脚 の建物では柱脚部分でなく，1階の柱の脚部が損傷している。しかし ながら、ここではそのような破壊に対しては触れない。

表 1 に本検討の対象とする激震地にありながら柱脚部は無被害で あった建物のリスト，表 2 に柱脚部に被害のあった建物のリストを示 す。日本建築学会・鎆コンクリート構造運営委員会が調查対象とした S R C 造建物は1307棟であり，そのうち震度VI地域あったものは731 棟である。柱脚部に被害のあったと判明した建物は43棟で，そのうち 震度VI地域あったものは37棟で，図面等が入手できた建物は10棟であ る。震度叫地域にありながら，柱脚部には被害の無かった建物は引き 算をすると最大 694 棟あり，そのうちの半数近くが非埋込み柱脚を有 していると考えられるが, 筆者等が図面等のデータを入手出来たもの は13棟である。被害を受けた43棟の建物データから被害の全体像を垷 み, 更に図面等が入手できた建物については無被害の建物も合わせて より詳細な検討を行う。柱脚部に被害を受けた建物のうち 1 階中途に 柱脚を設置した建物（No. 41）を除いて崩壊した建物はない。なお，表 中の空欄はデータが不明であることを示す。
* 青水建設建築本部技術部 主查·工博

**福山大学 教授・工博
Manager, Construction Technology Department, Shımızu Corporatıon, Dr Eng Prof, Fukuyama Unıversity, Dr Eng 
表 1 激拿地にあった柱脚部無被害建物

\begin{tabular}{|c|c|c|c|c|c|c|c|c|}
\hline No. & $\begin{array}{l}\text { 建物 } \\
\text { 用途 }\end{array}$ & 階数 & 竣工 & $\begin{array}{l}\text { 鉄骨 } \\
\text { 形式 }\end{array}$ & $\begin{array}{l}\text { 埋込 } \\
\text { 形式 }\end{array}$ & 被災度 & $\begin{array}{l}\text { 主被災 } \\
\text { 部位 }\end{array}$ & 震度 \\
\hline 1 & 事務所 & 9 & 1990 & 充腹 & 非埋込 & 軽微 & 外壁 & VII \\
\hline 2 & 事務所 & 8 & 1991 & 充腹 & 非埋込 & 中破 & 外壁,柱 & VI \\
\hline 3 & 共同住宅 & 7 & 1991 & 充腹 & 非埋込 & 中破 & 接合部 & VI \\
\hline 4 & 百貨店 & $2-9$ & 1966 & 非充腹 & 非埋込 & 中破 & 壁 & VII \\
\hline 5 & 事務所 & $1-6$ & 1965 & 非充腹 & 非埋込 & 大破 & 壁, 柱 & VI \\
\hline 6 & 事務所 & $1-9$ & 1988 & 充腹 & 非埋込 & 軽微 & & VII \\
\hline 7 & 事務所 & $2-13$ & 1982 & 充腹 & 非埋込 & 中破 & 壁, 柱 & VII \\
\hline 8 & 事務所 & $3-12$ & 1971 & 非充腹 & 非埋込 & 層崩壊 & 壁, 柱 & VII \\
\hline 9 & 事務所 & $1-8$ & 1986 & 充腹 & 非埋込 & 軽微 & & VII \\
\hline 10 & ホテル & $2-9$ & 1981 & 充腹 & 非埋込 & 軽微 & & VII \\
\hline 11 & 事務所 & $2-8$ & 1970 & 充腹 & 非埋込 & 中破 & 壁, 柱 & VII \\
\hline 12 & 事務所 & $1-7$ & 1973 & 充腹 & 非埋込 & 軽微 & & VII \\
\hline 13 & ホテル & $1-11$ & 1989 & 充腹 & 非埋込 & 小破 & 壁,柱 & VII \\
\hline
\end{tabular}

表 2 激震地にあった柱脚部被害建物

\begin{tabular}{|c|c|c|c|c|c|c|c|c|}
\hline No. & $\begin{array}{l}\text { 建物 } \\
\text { 用途 }\end{array}$ & 階数 & 帟工 & $\begin{array}{l}\text { 鉄骨 } \\
\text { 形式 }\end{array}$ & $\begin{array}{l}\text { 埋込 } \\
\text { 形式 }\end{array}$ & 被災度 & $\begin{array}{l}\text { 破壊 } \\
\text { モード }\end{array}$ & 震度 \\
\hline 1 & 運動施設 & 4 & 1973 & & 非埋込 & 大破 & 1,3 & VII \\
\hline 2 & 共同住宅 & 14 & 1971 & 格子 & 非埋込 & 大破 & 1 & VII \\
\hline 3 & 共同住宅 & 11 & 1971 & ラチス & 非埋込 & 大破 & $1,2,3$ & VII \\
\hline 4 & 共同住宅 & 11 & 1982 & 充腹 & 非埋込 & 大破 & $1,2,3$ & VII \\
\hline 5 & 共同住宅 & 8 & 1975 & 格子 & 非埋込 & 大破 & $1,2,3$ & VII \\
\hline 6 & 事務所 & 9 & 1984 & 充腹 & 非埋込 & 大破 & 1,3 & VII \\
\hline 7 & 事務所 & 8 & 1987 & 充腹 & 非埋込 & 大破 & $1,2,3$ & VII \\
\hline 8 & 事務所 & 8 & 1979 & & & 大破 & & VII \\
\hline 9 & 事務所 & 7 & 1973 & & & 大破 & & VII \\
\hline 10 & 事務所 & 9 & & & & 大破 & & VII \\
\hline 11 & 会館 & 8 & 1970 & & & 大破 & & VI \\
\hline 12 & 事務所 & 9 & 1965 & & & 大破 & & VII \\
\hline 13 & 事務所 & 9 & 1987 & 充腹 & 非埋込 & 大破 & 1 & VII \\
\hline 14 & 事務所 & 4 & 1990 & 充腹 & 非埋込 & 大破 & 2 & VII \\
\hline 15 & 共同住宅 & 12 & 1965 & 格子 & & 大破 & & VII \\
\hline 16 & 共同住宅 & 10 & 1971 & & & 大破 & & VII \\
\hline 17 & 共同住宅 & 11 & 1984 & 充腹 & 非埋込 & 大破 & 1 & VII \\
\hline 18 & 店舗 & 5 & 1974 & ラチス & 非埋込 & 大破 & 1,3 & VII \\
\hline 19 & 共同住宅 & 8 & 1973 & 格子 & 非埋込 & 中破 & 1 & VII \\
\hline 20 & 共同住宅 & 11 & 1979 & 充腹 & 埋込 & 中破 & 1 & VII \\
\hline 21 & 共同住宅 & 11 & 1979 & 充腹 & 埋込 & 中破 & 1 & VII \\
\hline 22 & 共同住宅 & 10 & 1979 & 充腹 & 埋込 & 中破 & 1 & VII \\
\hline 23 & 共同住宅 & 8 & 1976 & & & 中破 & & VII \\
\hline 24 & 共同住宅 & 10 & 1978 & 充腹 & 埋込 & 大破 & & VII \\
\hline 25 & 事務所 & 10 & & & & 中破 & & VII \\
\hline 26 & 事務所 & 7 & 1965 & 格子 & & 中破 & & VII \\
\hline 27 & 事務所 & 11 & 1985 & 充腹 & 柱中途 & 大破 & 1 & VII \\
\hline 28 & 店舖 & 8 & 1985 & 充腹 & & 中破 & & VII \\
\hline 29 & 事務所 & 9 & 1974 & & & 中破 & & VI \\
\hline 30 & 事務所 & 7 & 1966 & & & 中破 & & VII \\
\hline 31 & 事務所 & 7 & 1965 & & & 中破 & & VI \\
\hline 32 & 共同住宅 & 9 & 1985 & 充腹 & 非埋込 & 中破 & 1 & VII \\
\hline 33 & 共同住宅 & 12 & 1993 & 充腹 & 非埋込 & 中破 & 1 & VII \\
\hline 34 & 共同住宅 & 14 & 1993 & 充腹 & 非埋込 & 中破 & & VII \\
\hline 35 & 店舖 & 2 & 1985 & 充腹 & & 中破 & & VI \\
\hline 36 & 共同住宅 & 12 & 1978 & & & 中破 & & VII \\
\hline 37 & ホテル & 9 & 1986 & 充腹 & 非埋込 & 中破 & & VI \\
\hline 38 & ホテル & 6 & 1986 & 充腹 & 非埋込 & 中破 & & VII \\
\hline 39 & 事務所 & 5 & 1974 & & & 中破 & & VI \\
\hline 40 & 事務所 & 5 & 1985 & 充腹 & 非埋込 & 中破 & 2 & VII \\
\hline 41 & 事務所 & 9 & 1971 & 充腹 & 柱中途 & 崩墑 & 1,3 & VII \\
\hline 42 & 共同住宅 & 8 & 1979 & 充腹 & 埋込 & 中破 & 1 & VII \\
\hline 43 & 共同住宅 & 12 & 1988 & 充腹 & 非埋込 & 中破 & 1,3 & Vil \\
\hline
\end{tabular}

\section{3 柱脚部被害の梳計的検討}

柱脚部の被害が確認できた 43 棟の建物について, 比較的に簡単に 統計的検討を行える以下の (1) 〜 (5) の事唡について統計的検討 を行い，柱脚部被害の実態を浮かび上がらせる。

(1) 破壊モード

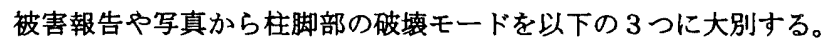
それぞれの破壊状況を写真 $1 ， 2 ， 3$ に示す。

破壊モード 1 柱脚部の主筋, アンカーボルト破断

破壊モード 2 柱脚部の主筋の付着破壤，抜けだし

破壊モード 3 ベースプレート位置の水平ずれ

柱脚部に被害のあった 43 棟の建物のうち破壊モードが資料より 判明できる 22 棟の建物の破壊モードの内訳を示す。一つの建物で 2 つ以上の破壊モードが重複しているものはそれぞれを 1 件としてい る。多くの建物で柱脚の主筋, アンカーボルト破断が報告されている。 ベースプレート位置のずれが報告されている建物ではすべてアンカ 一ボルト，主筋の破断が報告されている。

主筋の定着破壊，抜けだしのあった 6 件の建物のうち 2 件はアンカー ボルト，主筋の破断が報告されていない。
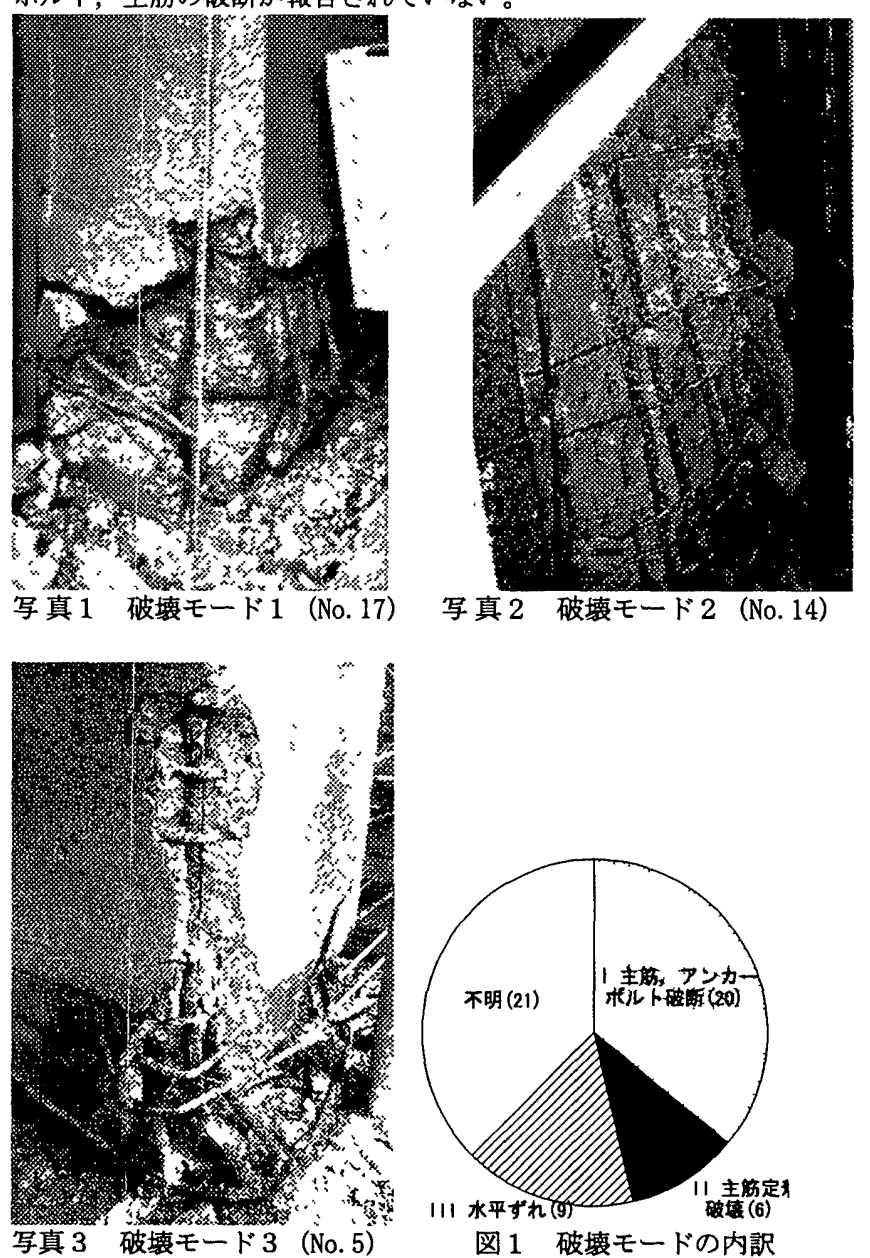

写真 2 破壊モード2 (No. 14)

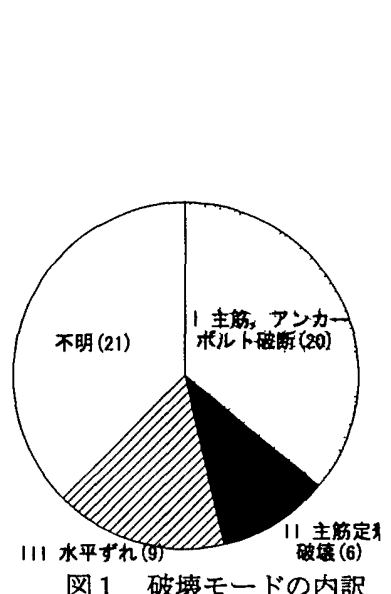

（2）柱脚部被害と柱脚形式および柱脚階

図 2 に被害のあった柱脚の形式を示す。ほとんどが非埋込み形式の 柱脚（19件）であるが埋込み柱脚の被害も5件ある。なお，柱の中 途，即ち計算上のモーメント 0 点近くに柱脚を固いている場合が 2 件 ある。そのうち 1 件は柱が落下し，1階の完全な層崩壊になっている。

図 3 に被害のあった柱脚部の設置階を示す。大部分が 1 階（28 件）であるが，地下階の場合が 6 件，中間階の場合が 2 件ある。地下 階に被害のあった建物のうち 2 件は地下階では中柱になるが，地上階 では外柱である柱の被害であり，2件は地下外壁付き柱の被害で，残 りの 2 件の状況は不明である。 


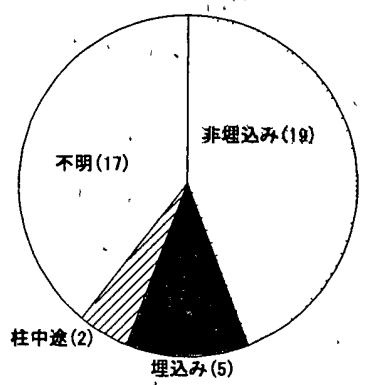

図 2、埋込交形式と被害件数

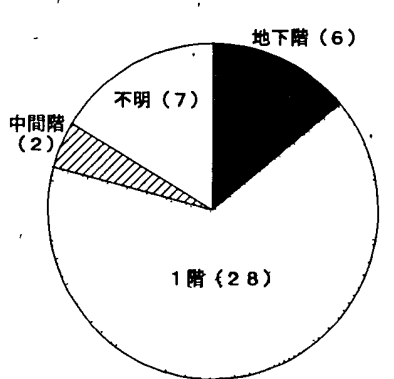

図 3 柱脚の設酔階
（3）柱脚部被害のあうた柱の種類と位置

図 4 に柱脚部に被害のあった柱で独立柱か, 壁付き柱かの区別のつ く資料のある 21 建物の柱の内訳を示す。層崩壊した建物はすべての 柱で被害があったとしている。直上階までその柱が壁付き柱であれば 壁付き柱としている。柱脚部に被害のあった柱の 7 割以上は壁付き柱 である。

図 5 に柱脚部に被害のあった柱で外柱か，中柱かの区別のつく凟料 のある 21 建物の柱の内訳を示す。ここで外柱とはXあるいY方向の いずれかで外柱であれば外柱としており，更に直上階までその柱が外 柱であれば外柱としている。柱脚に被害のあった柱の8割強は外柱で ある。また同じ建物でも外柱の被害が中柱の被害より大きいものが多 いと報告されている。

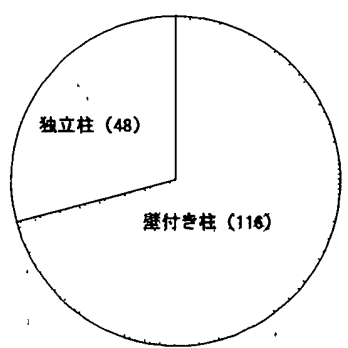

、図 4 壁付き柱の割合

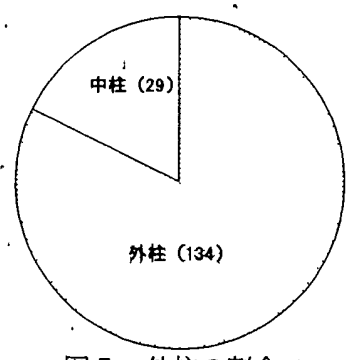

図 5 外柱の割合
（4）柱脚被害と竣工年代および鉄骨形式

図 6 に柱脚部に被害のあった建物の建設年代を示す。1981年に建築 基準法が改正され，それ以後の被害は城少したと言われている。しか しながら柱脚部の被害に関してはその傾向はなく, 新しい建物の被害 も古い建物に劣らず被害がある。㛊工年代と鉄骨形式は密接な関係が ある。1974年以前は主に非充腹形であり，1981年以後は主に充腹形で ある。

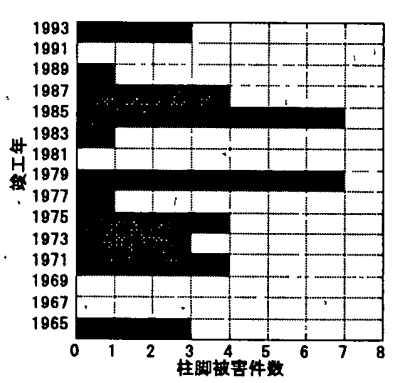

図 6 竣工年と柱脚部被害

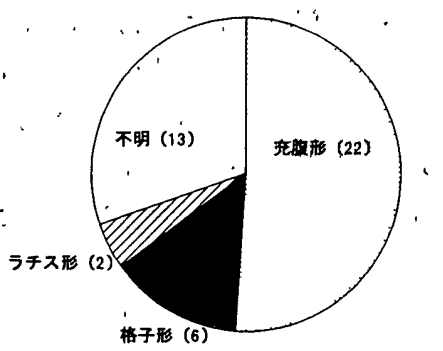

図 7 鉄骨形式と柱脚部被害
図 7 に鉄骨形式と被害の割合を示す。柱脚部に被害のあったものの
多くは充腹形の鉄骨を内蔵したものである。一般に充腹形 S R C 柱は 非充腹 S R C 柱よりも柱脚部で鋼材量が大きく減少する。

（5）柱脚部被害と塔状比および建物高さ

図 8 に柱脚部に被害のあった建物の塔状比 (建物高さ/幅)を示す。 実際に施工されるS R C 造建物の塔状比も $2 \sim 3$ のものが多いと思 われるので, 特に際だった傾向は図8から見られない。

図 9 に柱脚に被害のあった建物の高さを示す。建物が高くなると被 害件数も増えて $31 \mathrm{~m}$ 弱の建物が最も多く被害を受けている。 $31 \mathrm{~m}$ 以上 の建物では被害件数が減っている。1981年以降に建てられた $31 \mathrm{~m}$ 以上 の建物では設計時に保有耐力の検討が義務づけられる。

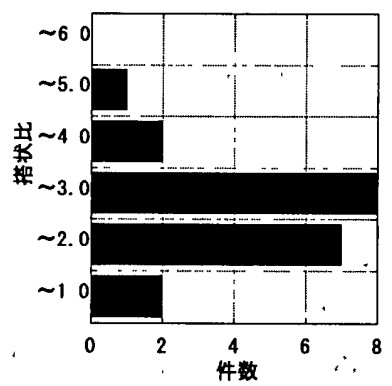

図 8 、塔状比と柱脚部被害

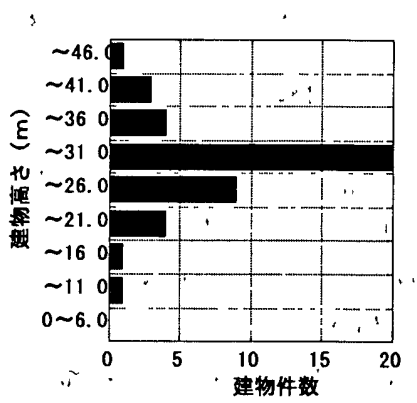

図 9 建物高さと柱脚部被害.

\section{(6) 考察}

統計的検討から柱脚部被害の原因を推定する。以下のことから上下 方向の引張力の影響が大きいと推察される。(1)主筋やアンカーボルト が破断しているモードが多い。(2)鉄骨がとぎれることにより銅材量が 大きく诚少する鉄骨量の多い充腹形の非埋込み柱脚に被害が多い。更 に以下のことから上下方向の地震力ではなく建物全体に働く転倒曲 げモーメントによる引張力の影響であることが推察される。(3)外柱や 壁付き柱の柱脚部に被害が多い。(4)高い建物の柱脚部に被害が多い。

\section{4. 転倒曲げ強度から推定される層せん断力係数}

3 章から, 地震時に建物に発生する転倒曲げモーメントにより生ず る引張力が柱脚部の破壊の一つの主要な原因と考えられる。ぞこで, 本章ではその影響を掘り下げて，柱の引張強度から計算される建物の 転倒曲げ强度, 更にはそれに等価な層せん断力保数を導き，3 章で述 べた被害との関係を骨組み構造と柱脚部の被害が顕著であった耐震 壁付き骨組みについて検討する。， 。

\section{（1）骨組み構造の場合}

地震力による転倒曲げに対しては図 10 に示すように外柱の軸力 の変化で抵抗すると考えると, 外柱の鋼材の引張降伏及び引張破断に 相当する当該階の層せん断力係数 $\mathrm{CBy}, \mathrm{CBu}_{\mathrm{Bu}}$ (1)，（2）式で表せる。 $\mathrm{h}$ は当該階より上部の水平力の作用重心高さで震度分布から計算さ れる值である。ただし， 5 章の実建物におけるC $\mathrm{CH}_{\mathrm{By}}$ の計算では計算の便 宜から $h=2 / 3 \mathrm{H}(\mathrm{H}$; 当該階より最上階までの高さ)を使っている。 $\mathrm{C}_{\mathrm{By}}=\left(0.75_{\mathrm{a}} \mathrm{a}_{\mathrm{g}} \cdot_{\mathrm{a}} \sigma_{\mathrm{y}}+{ }_{\mathrm{r}} \mathrm{a}_{\mathrm{g}} \cdot{ }_{\mathrm{r}} \sigma_{\mathrm{y}}+\mathrm{N}\right) \mathrm{d} / \mathrm{W} \cdot \mathrm{h}$

a $\mathrm{a}_{\mathrm{g}}$ : 外柱のアンカーボルトの軸部断面積

${ }_{\mathrm{a}} \sigma_{\mathrm{y}}:$ アンカーボルトの引張降伏強度

$\mathrm{r}_{\mathrm{a}}$ : 外柱の軸鉄筋の全断面積

${ }_{\mathrm{r}} \sigma_{\mathrm{y}}:$ 軸鉄筋の引張降伏強度 
$\mathrm{N}$; 外柱にかかる軸力

$\mathrm{d} ：$ 外柱の芯々間距離

田：当該骨組みにかかる重量

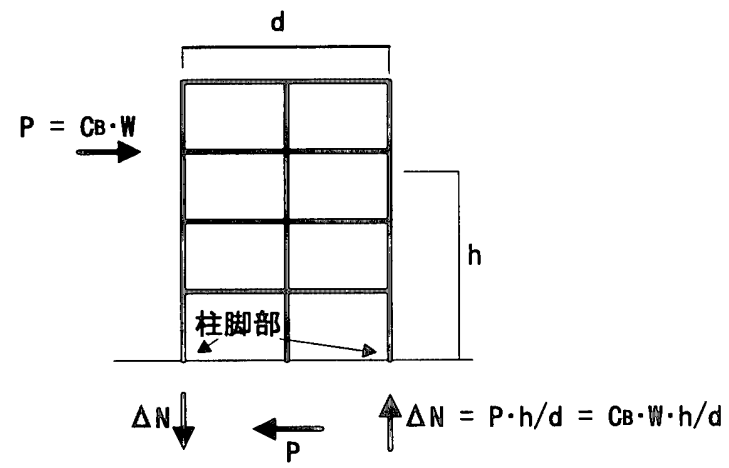

図 10 骨組みに働く転倒曲げモーメントの钓り合い

（2）耐震壁付き骨組み構造の場合

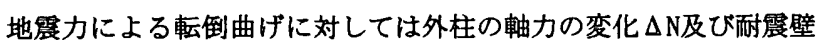
の曲げに伴う軸力変化 $\Delta$ Nwで抵抗すると考える。即ち，図11に示すよ うな均等なスパン長1wで， nスパンのうち外側から る（a）のモデルを考え，それをフレーム全体として転倒曲げに抵抗 する（b）のモデルと耐震壁にのみ曲げがかかる（c）のモデルに分 解する。梁の中央に反曲点があるとし，中柱に働くせん断力をQcとす る。耐譬壁がない場合には地硻力PはnQcになる。

これらの仮定は単純化して定式化が容易なように設けている。そこ でこれらの仮定から大きくずれる建物の場合に計算値には誤差が生 じる。かしながら, 概略評価のための簡便な評価式として本方法は 1つの有功な方法であると考える。

中柱に働くせん断力の合計は $(\mathrm{n}-\mathrm{m}-1) \mathrm{Qc}$ ，外柱一本に働くせん断力 はQc/2，耐裂壁に作用するせん断力は $(\mathrm{m}+1) Q \mathrm{c} / 2$ なので，（b ）の骨

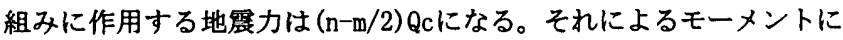

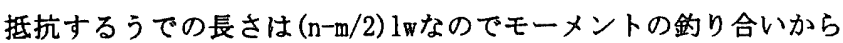

（3）式が得られる。（c）の耐震壁に働く地祳力Qwは $\mathrm{P}-(\mathrm{n}-\mathrm{m} / 2)$. Qc，而震壁の外側の側柱のみに変動軸力 $\Delta \mathrm{Nw}$ 倒くと考えると腕の長 さは1⿴・mとなり，モーメントの验り合いから（4）式が成り立つ。

$\Delta \mathrm{N}=\mathrm{Qc} \cdot \mathrm{h} / \mathrm{lw}$

$\Delta \mathrm{Nw}=[\mathrm{P}-(\mathrm{n}-\mathrm{m} / 2) \cdot \mathrm{Qc}] \mathrm{h} /(\mathrm{m} \cdot 1 \mathrm{w})$

耐震壁に取り付く柱に均等に $\Delta N$ N分配されるとすると，外柱に働 く引張力は $\Delta \mathrm{N} /(\mathrm{m}+1)+\Delta \mathrm{Nw}$ になるので, 外柱が降伏する場合には (5) 式が成り立つ。

$0.75_{\mathrm{a}} \mathrm{a}_{\mathrm{g}} \cdot_{\mathrm{a}} \sigma_{\mathrm{y}}+{ }_{\mathrm{r}} \mathrm{a}_{\mathrm{g}} \cdot_{\mathrm{r}} \sigma_{\mathrm{y}}+\mathrm{N}=\mathrm{Qc} \cdot \mathrm{h} /[1 \mathrm{w}(\mathrm{m}+1)]+[\mathrm{P}-(\mathrm{n}-\mathrm{m} / 2) \cdot$ Qc] $\mathrm{h} /(\mathrm{m} \cdot \mathrm{lw})$

両辺を重量Wで除し耐震壁付き骨組みのせん断力係数 $\mathrm{P} /$ 畉をC喵と置く と（6）式が得られる。

$\mathrm{CBP}=\left(0.75_{\mathrm{a}} \mathrm{a}_{\mathrm{g}} \cdot{ }_{\mathrm{a}} \sigma_{\mathrm{g}}+{ }_{\mathrm{r}} \mathrm{a}_{\mathrm{g}} \cdot{ }_{\mathrm{r}} \sigma_{\mathrm{y}}+\mathrm{N}\right) \cdot 1 \mathrm{w} / \mathrm{W} \cdot \mathrm{h}\{[1 / \mathrm{m}+[1 /(\mathrm{m}+1)$ $-n / m+1 / 2] \cdot Q c / P\}$

Qc/Pは中柱 1 本にかかるせん断力の骨組にかかるせん断力に対す る割合であるが, 計算の便宜のため中柱 1 本の强度の骨組のせん断強 度に対する割合とする。而眼壁がない場合の転倒曲げ降伏強度に対応 するせん断力係数CBy は（1）式のdをn・1四に㯰き換える事により得ら れるのでC $\mathrm{B}$ 的 $/ \mathrm{CBy}_{\mathrm{B}}$ は $(7)$ 式により得られる。
$\mathrm{CBW}_{\mathrm{BW}} / \mathrm{C}_{\mathrm{By}}=1 /(\mathrm{n} / \mathrm{m}+\mathrm{n}[1 /(\mathrm{m}+1)-\mathrm{n} / \mathrm{m}+1 / 2] \cdot \mathrm{Qc} / \mathrm{P})$

図 12 にスパン数 $\mathrm{n}$, 耐震壁のあるスパン数 $\mathrm{m}$ と $\mathrm{CB} / \mathrm{AB} / \mathrm{CB}$ の計算例

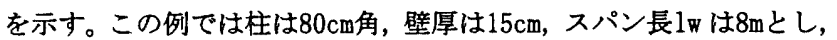
柱のせん断耐力 $\tau \mathrm{c}$ は $18 \mathrm{~kg} / \mathrm{cm}^{2}$, 壁のせん断強度 $\tau$ w は $30 \mathrm{~kg} / \mathrm{cm}^{2}$ とし ている。なお，（6）式は柱の强度を基淮にして解き起こしているの で柱の無い $\mathrm{m}=\mathrm{n}$ の場合は成立しない。 $\mathrm{m}=\mathrm{n}$ の場合は（1）式を用い てCB日を計算する。

耐繁壁付き骨組みでの外柱では，骨組み全体にかかる転倒曲げモー メントによる引張力と耐譬壁にかかる曲げによる引張力が重なるの で, CB⿴が低下する。壁の占めるスパン数 $\mathrm{m} か ゙$ 少ないと壁付き骨組みの 転倒曲げ強度比 $\mathrm{C}_{\mathrm{B}} / \mathrm{CB}_{\mathrm{y}}$ 惊小さくなり，また全体のスパン数が大きい

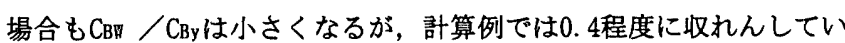
る。以上の理由により，既に図4に示したように兵庫県南部地覀では 壁付き柱に柱脚部の被害が多かったと推察される。

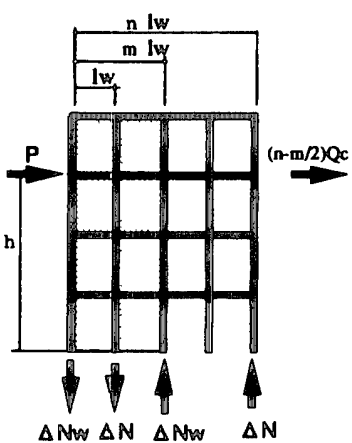

(a)

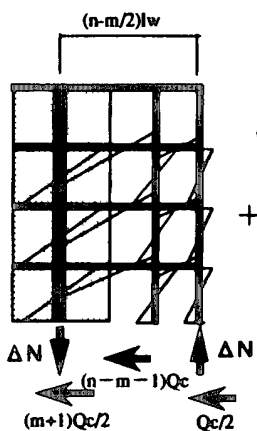

(b)

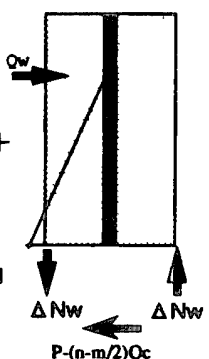

(c)
図 11 壁付き骨組みのモーメントの鲜り合い

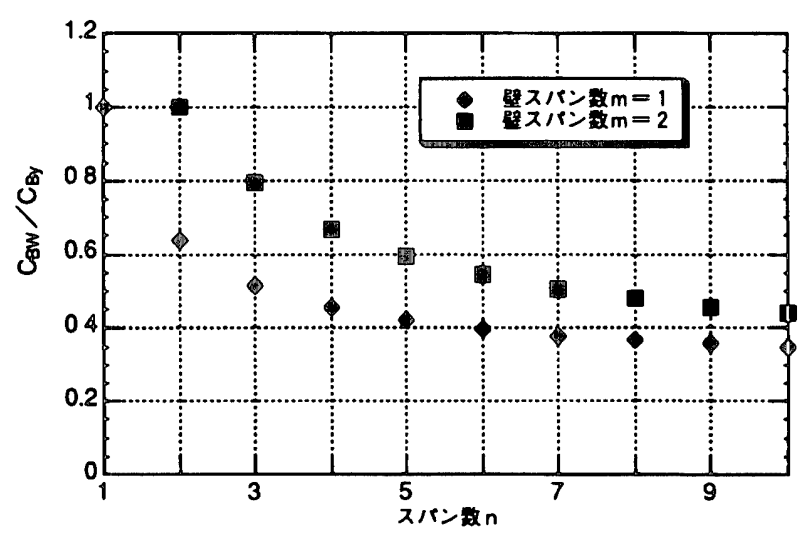

図 12 転倒曲げ強度比 $\mathrm{CB}$ / $/ \mathrm{CBy}$ と壁スパン数 $\mathrm{m}$, スパン数 $\mathrm{n}$

\section{（3）転倒曲げ強度と塔状比および建物高さ}

塔状比の影響を検討するためにnスパン建物の転倒曲げ強度に相当 するせん断力保数CBnについて検討する。均等なスパン長aで，中柱一 本あたりの軸力を $\mathrm{w}$, 外柱一本あたりの軸力を $\beta \mathrm{w}$ とする。建物にか かる水平力の重心高さをhとする。このモデルではスパン数nが增える と塔状比は小さくなる。図 13 に示寸転倒曲げモーメントの釣り合い から変動軸力 $\Delta N$ N $(8)$ 式で表せる。

$\Delta \mathrm{N}=\mathrm{C}_{\mathrm{Bn}}(\mathrm{n}-1+2 \beta) \mathrm{w} \cdot \mathrm{h} /(\mathrm{n} \cdot \mathrm{a})$

外柱の引張力 $\Delta N-\beta$ wを柱脚部の引張降伏強度と等置すると （9）式が得られる。 


$$
\begin{aligned}
C_{B n}= & \left\{\left(0.75_{\mathrm{a}} \mathrm{a}_{\mathrm{g}} \cdot{ }_{\mathrm{a}} \sigma_{\mathrm{y}}+{ }_{\mathrm{r}} \mathrm{a}_{\mathrm{g}} \cdot{ }_{\mathrm{r}} \sigma_{\mathrm{y}}\right) / \mathrm{w}+\beta\right\} \\
& \cdot \mathrm{n} \cdot \mathrm{a} / \mathrm{h}(\mathrm{n}-1+2 \beta)
\end{aligned}
$$

$0.5<\beta<1$ と考えられる。（9）式より $\beta=0.5$ とするとC $\mathrm{Bn}$ はスパ ン数 $\mathrm{n}$ と無関係になる。 $\mathrm{n}$ スパン建物と 1 スパン建物のせん断力係数 CB1の比は、(10) 式で表せる。

$$
\mathrm{C}_{\mathrm{Bn}} / \mathrm{C}_{\mathrm{BI}}=2 \beta \mathrm{n} /(\mathrm{n}-1+2 \beta)
$$

$\beta=0.5,0.8 ， 1.0$ についてスパン数と転倒曲げ强度の関係を図14 に示す。 $\beta=0.5$ 以外の場合はスパン数が増えると $\mathrm{C}_{\mathrm{Bn}} / \mathrm{C}_{\mathrm{B} 1}$ も増えるが 線形的には増えていかず，増え方は顕著でない。一方，建物を均一な 直方体と考えると縁応力度は $\mathrm{n}$ に反比例し $\mathrm{C}_{\mathrm{Bn}} / \mathrm{C}_{\mathrm{B} 1}=\mathrm{n}$ となるが，均 等スパンを仮定した実建物に近い本モデルの傾向とは大分違う。そこ で，2章で柱脚部の被害と塔状比に顕著な関係がないことも, 転倒曲 げを柱脚部被害の原因と考えることと矛盾しない。 $\beta=0.5$ の場合に はスパン数nには無関係でスパン長aに比例しฺて転倒曲げ強度は大き くなる。

水平力の重心高さhは（9）式の分母にあり更にwもhに比例して大 きくなるので，建物が高くなると転倒曲げ強度は急激に小さくなる。 それは 2 章で柱脚部の被害は建物高さが高くなる程, 顕著になること と符号する。 $31 \mathrm{~m}$ 以上の建物で柱脚部の被害が減ったが，1981年以降 に建てられた $31 \mathrm{~m}$ 以上の建物では保有耐力の検討が設計時になされ るので，引張力に対する配慮がそれなりになされるためと考えられる。 $31 \mathrm{~m}$ 以下の建物はベースシア係数 0.2 の小さい地震しか考慮しないの で, 設計時に長期軸力と打ち消しあい, 転倒曲げによる引張力はあま り生じない。そこで31 $\mathrm{m}$ 以下の建物の転倒曲げ強度に相当するせん断 力係数 は小さいと考えられる。

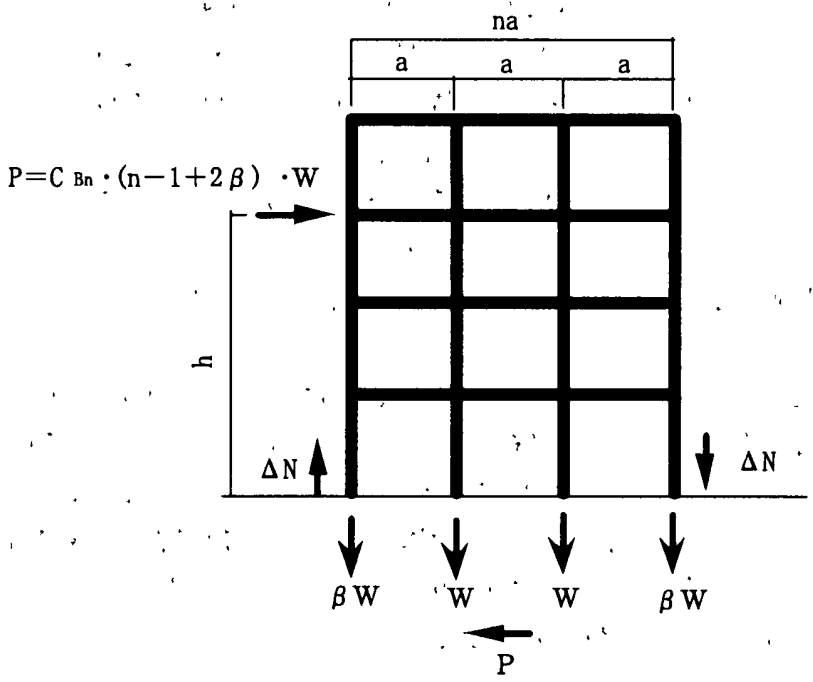

図 13 均等なスパンおよび階高の建物モデル

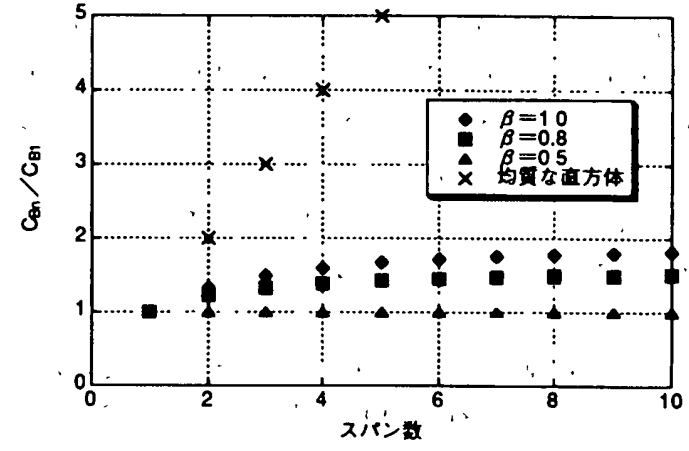

図 14 スパン数（塔状比）と転倒曲げ强度

\section{5 柱脚部引張破㙼の条件}

本章では図面 等の資料が得られた無被害建物13棟,・被害建物10棟 の柱について降伏転倒曲げ強度に相当するせん断力係数 $\mathrm{CBy}_{\mathrm{By}}$ (壁の影響 が大きいと考えられる柱の場合はCB⿴囗十)，C $\mathrm{By}$ の当該骨組みのせん断力 係数Coに対する比 $\mathrm{C}_{\mathrm{By}} / \mathrm{C}_{0}$, および柱脚／柱頭の降伏強度の比By/Tyを計 算し柱脚部引張破壊の条件を検討する。建物全体としてCo,Cを計算し ている場合も該当する柱毎にBy/Tyを計算している。柱計算結果一臨 を表 3 に示す。銅材の降伏強度は公称強度ではなく、診断基淮》に定め られた值を用いている。Coの計算は無被害建物のNo. 1,2および被害建 物のNo. 6は S R C 耐震診断基淮 3 の 2 次診断によっ.たが，その他のも のは詳しいデータが不足しているので 1 次診断によった。

表 3 資料の得られた建物の計算結果一筧

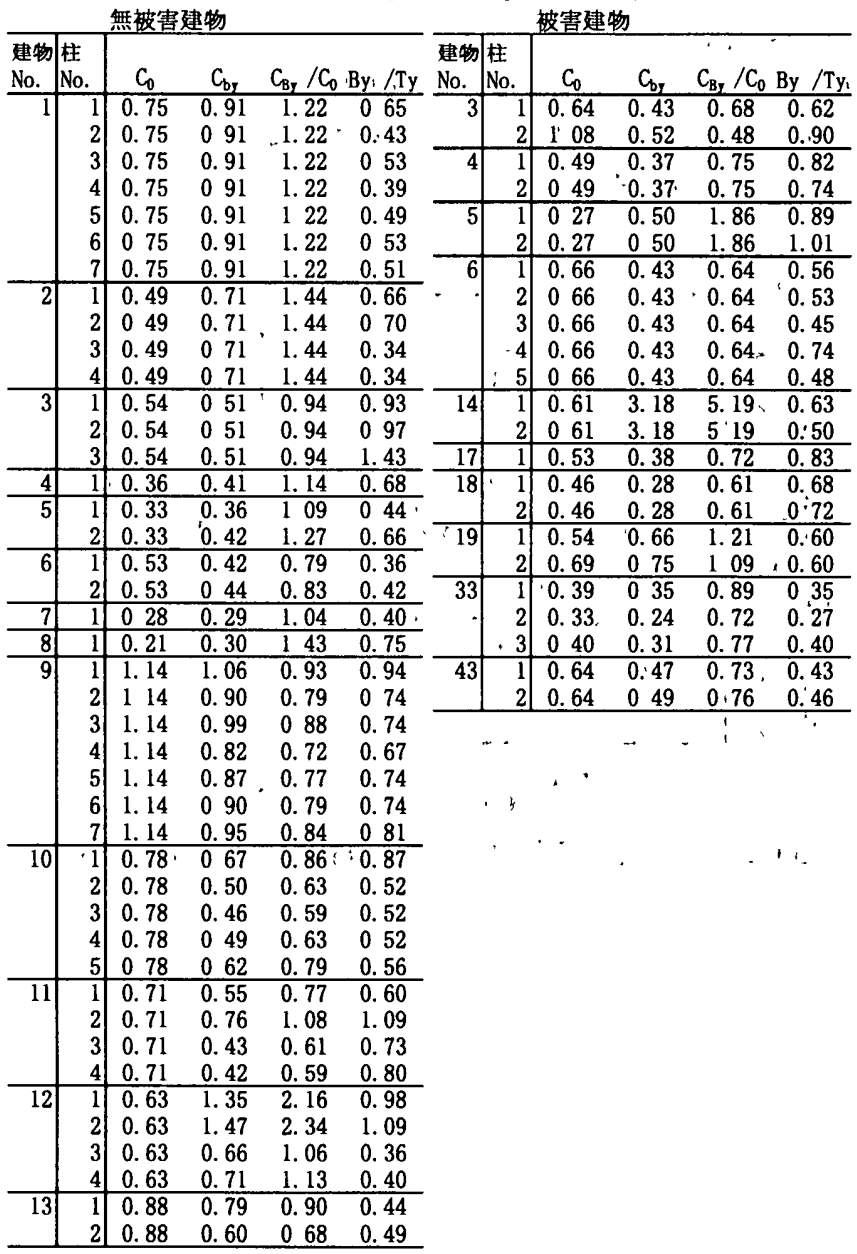


図 15 は縦軸に柱脚／柱頭の降伏強度の比By/Ty, 横軸に降伏転倒 曲げ強度に相当するせん断力係数 $\mathrm{CBy}_{\mathrm{By}}$ をとり，被害との関係を調へた ものである。被害を受けた柱脚の大部分はBy/Tyが 1 以下で, CBy 以下になっている。ただし, By/Tyが 1 程度でも柱脚部の破壊が生じ ている柱もある。この柱はNo.5の建物の柱で既に写真 3 に被害状況を 示してある。柱脚部でコンクリートを打ち継いでいるようであり，そ こで柱が滑っている。また，被りコンクリートが取れ，鉄筋の付着が 喪失している。C $C_{B y}$ が0.3から0.5以下の場合は無被害と被害を受けた 建物が混在している。図中にある No.19の建物および図からは大きく はみ出しているNo.14（表 3照）はCByが0.5を超えているにもかか わらず柱脚部の破壊が生じている。No.14は既に写真 2 に被害の様子 を示している。被りコンクリートが取れ，鉄筋の付着が乘失しており， 柱脚部の補強主筋が有効に引張力を負担できなかったようである。 No. 19の建物は付着亀裂が顕著であり柱脚部の施工状態が悪いと報告 されている。

当該層のせん断强度COがCBy に当該層の柱, 壁が破壊してしまう。そこで縦軸にCBy $/ C_{0}$ を横軸にCBy を採り被害との関倸を調べたものを図 16 に示す。 $\mathrm{CBy}_{\mathrm{By}}$ が0.4以下の 建物でも柱脚部の破壊が生じていない建物があるが，それらはC By $C_{0}>1$ となっており，先に柱や塈が壊れてしまい柱脚部の破壊が報告 されていないと考えられる。CByが0.4から0.5以下の場合は無被害と 被害を受けた建物が混在している。以上から，Сву が0.5以上あり， 施工上の問題が無く，柱脚部の補強主筋が有効に働く事ができれば, 柱脚部の被害は免れたといえる。

なお，柱脚部の被害を防ぐための条件としては本論で検討を行った $\mathrm{Cby}_{\mathrm{by}}, \mathrm{By} / \mathrm{Ty}, \mathrm{C}_{\mathrm{By}} / \mathrm{C}_{0}$ 等のパラメータの他に，梁降伏時あるいは終局 メカニズム時の引張力および曲げモーメントに耐えるように柱脚部 を設計する等も考えられる。

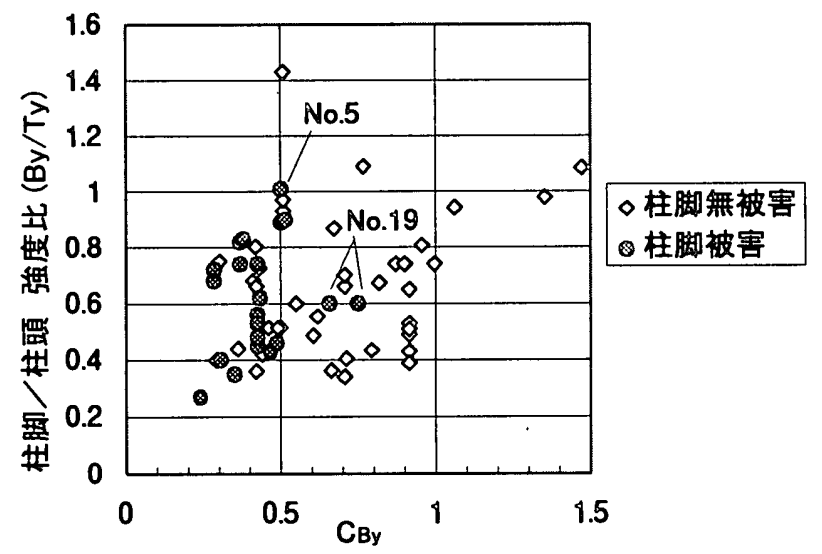

図 15 柱脚部被害と柱脚／柱頭の强度比，転倒曲け強度 $\mathrm{Cby}$

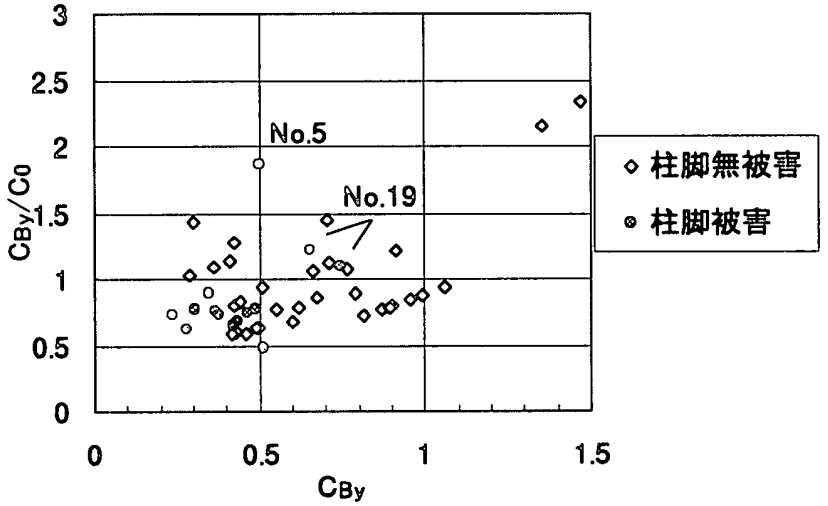

図 16 柱脚部被害と $\mathrm{CBy}_{\mathrm{By}} / \mathrm{C}_{0}$, 転倒曲げ強度 $\mathrm{C}_{\mathrm{By}}$

6. まと的

兵庫県南部地震で柱脚部に被害を受けた 43 棟のS R C 造建物, お よび激震地にありながら柱脚部には被害を受けなかった 13 棟のS $\mathrm{RC}$ 造建物について検討を行った。

統計的検討から以下の事が明らかにになり，地震時の転倒曲げによ る引張力が柱脚部の被害の主要な原因であると推察した。(1)主筋やア ンカーボルトが破断しているモードが多い。(2)鉄骨がとぎれることに より铜材量が大きく隇少する铁骨量の多い充腹形の非埋込み柱脚に 被害が多い。(3)外柱や壁付き柱の柱脚に被害が多い。(4)高い建物の柱 脚に被害が多い。

そこで更に原因を掘り下げ，骨組み構造，耐震壁付き骨組みについ て柱脚部に着目した建物の転倒曲げ強度に相当する等価なせん断力 俰数 $\mathrm{C}_{\mathrm{By}}$ ， $\mathrm{CB}_{\mathrm{Bw}}$ を求めるモデルを提案し，耐震壁付き骨組みでは骨組 み構造の半分近くまで等価なせん断力係数が低下すること, 建物が高 くなるとCBy は大きく低下寸るが塔状比にはあまり影響されない事を 示した。被災地の建物の計算結果からCBy が0.5以上の建物では柱脚 部の被害を受けにくいことを示した。

ただし， CBy が0.5以上の建物であっても被害を受けた建物が 2 件 ありそそれらの建物では柱脚部付近のコンクリート打ち継ぎ部の施工 状態が悪く脚部を補強している主筋が定着破壊を起こしていた。

謝辞 本論文に用いたデータの多くは日本建築学会銅コンクリート 合成構造運営委員会に奇せられたアンケートデータ及びS R C 耐晨 設計小委員会に提供されたデータに基つくものである。協力していた だいた方々に深謝の意を表します。また，建築防災協会：SＲＣ耐罢 診断基準改訂委員会の委員の方々にも貴重な御意見を戴いています。 委員の方々に深謝の意を表します。

\section{参考文献}

[1] 日本建築学会：阪神・淡路大震災調查報告 建築編一 $2 \quad 1998.8$ [2]称原良一，角陸純一，田中良三：兵庫県南部地震の S R C 建物の 被害検討 その 1 非埋込み柱脚の被害と原因について, 日本建築学 会大会講演梗概集C-1pp869-870, 1996.9

[3] 日本建築防災協会：改訂版 既存鉄骨鉄筋コンクリート造建築物 の耐震診断基淮同解説, 1997.12 